\title{
Estimating the Density of Honeybee Colonies across Their Natural Range to Fill the Gap in Pollinator Decline Censuses
}

\author{
RODOLFO JAFFÉ, ${ }^{*} \neq \ddagger \neq$ VINCENT DIETEMANN,${ }^{*} \dagger \neq$ MIKE H. ALLSOPP,$\oint$ CECILIA COSTA, ${ }^{* *}$ \\ ROBIN M. CREWE, $\neq$ RAFFAELE DALL'OLIO, ${ }^{* *}$ PILAR DE LA RÚA, †† MOGBEL A. A. EL-NIWEIRI, \\ INGEMAR FRIES, $\neq \ddagger$ NIKOLA KEZIC, $\S \S$ MICHAEL S. MEUSEL ${ }^{* * *}$ ROBERT J. PAXTON, ${ }^{*} \dagger \dagger$ \\ TAHER SHAIBI, ${ }^{*}$ ECKART STOLLE, ${ }^{*}$ AND ROBIN F.A. MORITZ* \\ ${ }^{*}$ Institut für Biologie, Martin-Luther-Universität Halle-Wittenberg, Hoher Weg 4, Halle (Saale) 06120, Germany \\ †Swiss Bee Research Center, Agroscope Liebefeld-Posieux Research Station ALP, Schwarzenburgstrasse 161, CH-3003 Bern, \\ Switzerland \\ ¥Social Insect Research Group, Department of Zoology and Entomology, University of Pretoria, Pretoria 0002, South Africa \\ $\S$ Honeybee Research Section, ARC-Plant Protection Research Institute, Private Bag X5017, Stellenbosch 7599, South Africa \\ ${ }^{* *}$ CRA-API, Unità di Ricerca di Apicoltura e Bachicoltura. Via di Saliceto 80, Bologna 40128, Italy \\ ††Área de Biología Animal, Departamento de Zoología y Antropología Física, Facultad de Veterinaria, Universidad de Murcia, 30100 \\ Murcia, Spain \\ ‡¥Department of Ecology, Swedish University of Agricultural Sciences, Box 7044, 75007 Uppsala, Sweden \\ $\S \S$ Faculty of Agriculture, University of Zagreb, Svetosimunska 25, HR-10000 Zagreb, Croatia \\ ${ }^{* * *}$ Discipline of Genetics, School of Biochemistry, Genetics, and Microbiology, University of KwaZulu-Natal, Pietermaritzburg, \\ Private Bag XO1, Scottsville 3209, South Africa \\ †††School of Biological Sciences, Queen's University Belfast, 97 Lisburn Road, Belfast BT9 7BL, United Kingdom
}

\begin{abstract}
Although pollinator declines are a global biodiversity threat, the demography of the western boneybee (Apis mellifera) has not been considered by conservationists because it is biased by the activity of beekeepers. To fill this gap in pollinator decline censuses and to provide a broad picture of the current status of honeybees across their natural range, we used microsatellite genetic markers to estimate colony densities and genetic diversity at different locations in Europe, Africa, and central Asia that had different patterns of land use. Genetic diversity and colony densities were highest in South Africa and lowest in Northern Europe and were correlated with mean annual temperature. Confounding factors not related to climate, however, are also likely to influence genetic diversity and colony densities in boneybee populations. Land use showed a significantly negative influence over genetic diversity and the density of honeybee colonies over all sampling locations. In Europe boneybees sampled in nature reserves had genetic diversity and colony densities similar to those sampled in agricultural landscapes, which suggests that the former are not wild but may have come from managed hives. Other results also support this idea: putative wild bees were rare in our European samples, and the mean estimated density of honeybee colonies on the continent closely resembled the reported mean number of managed hives. Current densities of European boneybee populations are in the same range as those found in the adverse climatic conditions of the Kalahari and Saharan deserts, which suggests that beekeeping activities do not compensate for the loss of wild colonies. Our findings highlight the importance of reconsidering the conservation status of honeybees in Europe and of regarding beekeeping not only as a profitable business for producing boney, but also as an essential component of biodiversity conservation.
\end{abstract}


Keywords: Apis mellifera, beekeeping, ecosystem functioning, honeybee conservation, land use, pollinator decline

Estimación de la Densidad de Colonias de Abejas en su Rango Natural para Cerrar la Brecha en los Censos del Declive de Polinizadores

Resumen: Aunque la declinación de polinizadores es un amenaza global para la biodiversidad, la demografía de la abeja (Apis mellifera) no ha sido considerada por conservacionistas ya que está sesgada por la actividad de los apicultores. Para cerrar esta brecha en los censos del declive de polinizadores y proporcionar una visión amplia del estatus actual de las abejas en su rango natural, utilizamos marcadores genéticos de microsatélites para estimar las densidades de colonias y la diversidad genética en diferentes localidades en Europa, África y Asia central que tenían diferentes patrones de uso de suelo. La diversidad genética y las densidades de colonias fueron mayores en África del Sur y menores en el norte de Europa y se correlacionaron con la temperatura media anual. Sin embargo, es probable que factores de confusión no relacionados con el clima también afecten a la diversidad genética y las densidades de colonias en poblaciones de abejas. El uso de suelo mostró tener una influencia significativamente negativa sobre la diversidad genética y la densidad de colonias de abejas en todas las localidades de muestreo. La diversidad genética y densidades de colonias de las abejas muestreadas en reservas naturales de Europa fueron similares a las de paisajes agrícolas, lo que sugiere que las primeras no son silvestres sino que pudieron provenir de colmenas comerciales. Otros resultados también soportan esta idea: abejas tentativamente silvestres fueron raras en nuestras muestras europeas y la densidad promedio de colonias de abejas estimada en el continente se aproxima bastante al número promedio de colmenas comerciales reportado. Las densidades actuales de abeja europea están en el mismo rango que las encontradas en las condiciones climáticas adversas de los desiertos Kalahari y Sabara, lo que sugiere que las actividades apícolas no compensan la pérdida de colonias silvestres. Nuestros resultados resaltan la importancia de revisar el estatus de conservación de las abejas en Europa y de considerar a la apicultura no solo como un negocio rentable para la producción de miel, sino también como un componente esencial de la conservación de la biodiversidad.

Palabras Clave: apicultura, Apis mellifera, conservación de abejas, declive de polinizadores, funcionamiento del ecosistema, uso de suelo

\section{Introduction}

Pollination is an important ecosystem service because the majority of wild plants are insect pollinated, as are most commercial crops (e.g., Buchmann \& Nabhan 1996; Constanza et al. 1997; Klein et al. 2007). Pollinators, however, are under increasing threat from anthropogenic factors, including fragmentation and destruction of natural habitats through intensive land use, toxic pesticides used in agriculture, and invasive plant and animal species and their diseases (Allen-Wardell et al. 1998; Brown \& Paxton 2009; but see also Ghazoul 2005). Without pollinators, ecosystem functioning, trophic cascades, and the survival and maintenance of genetic diversity of many wild plant populations would be at risk (Kearns et al. 1998), and economic yields of crops may suffer a drastic reduction (Gallai et al. 2009).

Even though pollinator declines are a global biodiversity threat, the demography of the western honeybee (Apis mellifera) has not been taken into account by conservationists because it is influenced by the activities of beekeepers and therefore is regarded as unnatural (e.g., Kremen et al. 2002). Nevertheless, honeybees are key generalist pollinators. They live in large perennial colonies that ensure high local pollination throughout the flowering season (Seeley 1985) and have a vast foraging area that enhances gene flow in plant communities (Roubik 1989; Free 1993). The western honeybee is endemic to Africa, Europe, and the Middle East (Ruttner 1988; Whitfield et al. 2007), but has been introduced worldwide for exploitation as a honey producer and crop pollinator (Huryn 1997; Moritz et al. 2005). Despite their commercial use, honeybees have suffered a progressive decline throughout the world over recent decades (Matheson et al. 1996). The recent occurrence of so-called colony collapse disorder (CCD) in the United States and a similar phenomena in Europe resulted in the death of hundreds of thousands of colonies (van Engelsdorp et al. 2008).

The global decline of managed honeybees has been discussed primarily in light of the important economic losses they represent (Southwick \& Southwick 1992; Morse \& Calderone 2000; Allsopp et al. 2008), and little attention has been paid to wild and feral honeybee populations (Moritz et al. 2005). Wild populations are important reservoirs of local adaptations that ultimately determine the survival of honeybees in the wild (Matheson et al. 1996). Moreover, a simultaneous decline of wild and managed honeybees may have dramatic consequences on pollination services to crops and natural 
ecosystems (Gallai et al. 2009). On the basis of questionable evidence for competition between honeybees and other native pollinators (reviewed by Huryn 1997 and Paini 2004, but see Roubik \& Wolda 2001), many European governments (e.g., Belgium, Netherlands, United Kingdom) have implemented national policies that exclude managed pollinators from protected areas (e.g., sections 14 and 16 of the Wildlife and Countryside Act 1981, United Kingdom). In contrast, on the basis of the same evidence, other countries such as Germany and Austria, permit apiculture within designated protected areas. The inconsistency in honeybee conservation policies across Europe and the magnitude of recent colony losses justify the inclusion of $A$. mellifera in pollinator abundance surveys.

The real magnitude of pollinator declines is not easily determined and has been the subject of a controversial review (Ghazoul 2005). Accurate measurements of population densities are essential for any meaningful assessment of decline (Paini 2004). For nonsocial pollinators this can be done with direct counts of individuals and classical abundance measures. For social bees, however, the number of colonies rather than the number of individuals is the crucial parameter for conservation. The number of colonies in the wild is, nevertheless, very difficult to assess. Density estimates derived from direct counts of feral and wild honeybee colonies are tedious and can be unreliable because natural nests are hard to detect (Otis 1991; McNally \& Schneider 1996; Oldroyd et al. 1997). Molecular DNA tools are a more effective mean to assess honeybee population density (Estoup et al. 1995; Moritz et al. 2007). In particular, the use of tightly linked microsatellite DNA markers to reconstruct queen genotypes from samples of honeybee drones or workers is the most powerful tool currently available (Shaibi et al. 2008) that allows recognition of the offspring of closely related queens (Jaffé et al. 2009). We used these genetic markers to quantify the density of $A$. mellifera colonies in natural and agricultural landscapes of Europe, Africa, and central Asia and identified the factors influencing the current demography of honeybees. In addition, to provide insights into the demographic status of feral and wild honeybee populations in Europe, we contrasted our estimates with the number of managed colonies surrounding the sampling locations where beekeeping occurs.

\section{Methods}

\section{Sampling}

We collected honeybee samples from 25 locations (10 in Africa, 2 in central Asia, and 13 in Europe; see Supporting Information for coordinates and climatic data). Honeybee drones gather at drone congregation areas (DCAs) that virgin queens visit to mate with tens of partners
(Ruttner \& Ruttner 1972; Moritz \& Southwick 1995). The DCAs attract drones from most colonies within recruitment range (Baudry et al. 1998; Jaffé et al. 2009), so genotyping drones collected from a DCA allows estimating the number of drone-contributing colonies within the recruitment perimeter of the DCA (i.e., the density of colonies). Honeybee drones can be lured by synthetic queen pheromone into a trap kept approximately $20 \mathrm{~m}$ above ground by a weather balloon (Williams 1987). We captured drones from previously identified DCAs, by flying the pheromone trap between 12:00 and 17:00, under sunny and windless conditions, during the swarming season.

At 12 locations where beekeeping is practiced, we alternatively collected worker offspring from 10 managed colonies headed by locally mated queens (Table 1). Honeybee queens mate with many haploid drones (Moritz \& Southwick 1995). By genotyping workers of a single queen, it is possible to deduce the genotype of the queen and that of her mates (Estoup et al. 1994). To avoid sampling workers that drifted from a foreign colony into the sample hive, we collected young worker bees directly from the combs upon opening of the hives. With this approach, failing to detect some fathers in a colony would be equivalent to failing to sample some drones at a DCA. Individuals were stored in 95\% ethanol until genetic analysis.

\section{Genotyping}

We used different sets of microsatellite markers to determine individual genotypes (Table 1) and a Chelex protocol to extract DNA (Walsh et al. 1991). The microsatellite target sequences were amplified by multiplex polymerase chain reactions (PCR) with fluorescently labeled primers. Samples containing no DNA were included in all plates as negative controls. We then resolved PCR products in a MegaBACE 1000 capillary sequencer and determined allele sizes with the Fragment Profiler software (Amersham Biosciences, Germany).

\section{Genetic Diversity Measures and Reconstruction of Queen Genotypes}

For each sample set, we constructed tables with the genotypes of all drones (obtained either directly, by genotyping drones caught in a DCA, or indirectly, by inferring their genotype from worker offspring of a single queen). Per locus allelic richness (AR) and gene diversity (expected heterozygosity, $H_{e}$ ) were calculated with FSTAT (version 2.9.3.2; Goudet 2002). Because drones are produced parthenogenetically and only carry alleles from their mother, genotyping drones allows for their assignment to specific queens. To reconstruct the genotype of individual drone-producing queens, we performed a sibship reconstruction analysis employing COLONY (version 1.3; Wang 2004). 
Table 1. Sample sizes, genetic diversity measures, nondetection errors, and number of estimated and managed honeybee colonies in 25 sampling locations spaced across Africa, central Asia, and Europe.

\begin{tabular}{|c|c|c|c|c|c|c|c|c|c|}
\hline Location & Sample ${ }^{a}$ & $\mathrm{n}^{b}$ & $\begin{array}{l}\text { Allelic } \\
\text { richness } \\
\text { (SD) }\end{array}$ & $\begin{array}{l}\text { Heterozygosity } \\
\text { (SD) }\end{array}$ & $N D E^{c}$ & $\begin{array}{l}\text { Number of } \\
\text { colonies } \\
\text { median }^{d}\end{array}$ & Total $^{e}$ & Managed $f$ & Source ${ }^{l}$ \\
\hline \multicolumn{10}{|l|}{ Africa } \\
\hline $\begin{array}{l}\text { Al Kufrah, } \\
\text { Libya }^{g}\end{array}$ & W & 183 & $7.92(3.58)$ & $0.73(0.04)$ & $5.3 \times 10^{-5}$ & $29(1)$ & 45 & 176 & local beekeeper \\
\hline $\begin{array}{l}\text { Khartoum, } \\
\text { Sudan }^{b}\end{array}$ & W & 58 & $8.24(3.50)$ & $0.75(0.07)$ & $4.2 \times 10^{-2}$ & $19(4)$ & 23 & $15 *$ & local beekeeper \\
\hline El-Faw, Sudan ${ }^{b, i}$ & W & 56 & $7.25(1.89)$ & $0.77(0.04)$ & $3.2 \times 10^{-2}$ & $19(4)$ & 23 & $0 *$ & - \\
\hline $\begin{array}{l}\text { Leeuwfontein, } \\
\quad \text { South Africa }{ }^{j, i}\end{array}$ & $\mathrm{D}$ & 96 & $16.99(3.31)$ & $0.88(0.01)$ & $8.4 \times 10^{-10}$ & $17(0)$ & 23 & $0 *$ & - \\
\hline $\begin{array}{l}\text { Ezemvelo, } \\
\quad \text { South Africa } \\
\end{array}$ & $\mathrm{D}$ & 96 & $18.02(4.85)$ & $0.91(0.01)$ & $1.5 \times 10^{-10}$ & $24(2)$ & 37 & $0 *$ & - \\
\hline $\begin{array}{l}\text { Suikerbosrand, } \\
\text { South Africa } \\
\end{array}$ & $\mathrm{D}$ & 191 & $16.68(4.79)$ & $0.77(0.02)$ & $2.0 \times 10^{-7}$ & $23(0)$ & 34 & $0 *$ & - \\
\hline $\begin{array}{l}\text { Tswalu, South } \\
\text { Africa }^{b, i}\end{array}$ & $\mathrm{D}$ & 148 & $11.92(1.37)$ & $0.79(0.06)$ & $3.6 \times 10^{-2}$ & $14.5(2)$ & 29 & $0 *$ & - \\
\hline $\begin{array}{l}\text { Pietermar- } \\
\text { itzburg, South } \\
\text { Africa }^{g, i}\end{array}$ & $\mathrm{D}$ & 96 & $12.36(5.34)$ & $0.82(0.05)$ & $1.9 \times 10^{-5}$ & $25(5)$ & 52 & $0 *$ & - \\
\hline $\begin{array}{l}\text { Elsenburg, } \\
\text { South Africa }{ }^{g}\end{array}$ & $\mathrm{D}$ & 95 & $10.22(2.76)$ & $0.81(0.01)$ & $4.8 \times 10^{-4}$ & $17(1)$ & 29 & 57 & $\begin{array}{l}\text { ARC-Plant } \\
\text { Protection } \\
\text { Research } \\
\text { Institute, } \\
\text { Honeybee } \\
\text { Research } \\
\text { Section, South } \\
\text { Africa }\end{array}$ \\
\hline $\begin{array}{l}\text { Jonkershoek, } \\
\text { South Africa } \\
\text { gei }\end{array}$ & $\mathrm{D}$ & 96 & $11.81(3.26)$ & $0.84(0.02)$ & $3.8 \times 10^{-5}$ & $26(3)$ & 40 & $0 *$ & - \\
\hline \multicolumn{10}{|l|}{ Central Asia } \\
\hline $\begin{array}{l}\text { Dshuuku, } \\
\text { Kyrgyzstan }^{k}\end{array}$ & W & 67 & $7.44(4.77)$ & $0.71(0.05)$ & $3.9 \times 10^{-5}$ & $14(1)$ & 21 & 60 & local beekeeper \\
\hline $\begin{array}{c}\text { Tjurgen-Ak-Suu, } \\
\text { Kyrgyzstan }^{k}\end{array}$ & W & 62 & $6.48(3.70)$ & $0.72(0.04)$ & $2.5 \times 10^{-7}$ & $12(1)$ & 23 & 40 & local beekeeper \\
\hline \multicolumn{10}{|l|}{ Europe } \\
\hline $\begin{array}{l}\text { Caravaca de la } \\
\text { Cruz, Spain }\end{array}$ & W & 233 & $8.84(5.28)$ & $0.66(0.09)$ & $3.1 \times 10^{-4}$ & $22(0)$ & 37 & 100 & $\begin{array}{l}\text { Veterinary Faculty } \\
\text { University of } \\
\text { Murcia, Spain }\end{array}$ \\
\hline Farindola, Italy ${ }^{b}$ & W & 110 & $8.71(3.10)$ & $0.75(0.07)$ & $1.6 \times 10^{-2}$ & $37(8)$ & 45 & $25 *$ & CRA-API, Italy \\
\hline $\begin{array}{l}\text { Intermesoli, } \\
\text { Italy }\end{array}$ & W & 108 & $9.97(3.23)$ & $0.84(0.02)$ & $2.0 \times 10^{-2}$ & $33(6)$ & 39 & 45 & CRA-API, Italy \\
\hline Elba, Italy ${ }^{b}$ & W & 102 & $11.06(5.43)$ & $0.74(0.08)$ & $1.9 \times 10^{-2}$ & $34.5(7)$ & 42 & 50 & CRA-API, Italy \\
\hline $\begin{array}{l}\text { Svinjicko, } \\
\text { Croatia }^{g}\end{array}$ & $\mathrm{D}$ & 96 & $9.94(6.58)$ & $0.71(0.08)$ & $1.3 \times 10^{-4}$ & $17(2)$ & 35 & 50 & $\begin{array}{l}\text { Faculty of } \\
\text { Agriculture, } \\
\text { University of } \\
\text { Zagreb, Croatia }\end{array}$ \\
\hline $\begin{array}{r}\text { Pokupsko, } \\
\text { Croatia }^{g}\end{array}$ & $\mathrm{D}$ & 96 & $9.58(5.67)$ & $0.63(0.09)$ & $1.9 \times 10^{-3}$ & $15(0)$ & 22 & 300 & $\begin{array}{l}\text { Faculty of } \\
\text { Agriculture, } \\
\text { University of } \\
\text { Zagreb, Croatia }\end{array}$ \\
\hline $\begin{array}{l}\text { Schwarzenau, } \\
\text { Germany }\end{array}$ & $\mathrm{W}$ & 92 & $4.35(2.18)$ & $0.67(0.06)$ & $8.9 \times 10^{-5}$ & $10(0)$ & 19 & $\mathrm{n} / \mathrm{a}$ & - \\
\hline Halle, Germany ${ }^{g}$ & $\mathrm{D}$ & 95 & $8.58(4.75)$ & $0.70(0.06)$ & $3.8 \times 10^{-4}$ & $17(1)$ & 30 & 32 & $\begin{array}{c}\text { Kreisimkerverein } \\
\text { Halle e.V., } \\
\text { Germany }\end{array}$ \\
\hline $\begin{array}{l}\text { Hochharz, } \\
\text { Germany }^{j}\end{array}$ & W & 77 & $6.64(5.65)$ & $0.68(0.08)$ & $1.6 \times 10^{-4}$ & $11(0)$ & 20 & $\mathrm{n} / \mathrm{a}$ & - \\
\hline $\begin{array}{l}\text { Müritz, } \\
\quad \text { Germany }^{j}\end{array}$ & W & 101 & $5.69(4.25)$ & $0.71(0.05)$ & $7.1 \times 10^{-5}$ & $16(0)$ & 23 & $\mathrm{n} / \mathrm{a}$ & - \\
\hline
\end{tabular}




\begin{tabular}{|c|c|c|c|c|c|c|c|c|c|}
\hline Location & Sample ${ }^{a}$ & $\mathrm{n}^{b}$ & $\begin{array}{c}\text { Allelic } \\
\text { richness } \\
\text { (SD) }\end{array}$ & $\begin{array}{c}\text { Heterozygosity } \\
\text { (SD) }\end{array}$ & $N D E^{c}$ & $\begin{array}{c}\text { Number of } \\
\text { colonies } \\
\text { median }^{d}\end{array}$ & Total ${ }^{e}$ & Managedf & Source ${ }^{l}$ \\
\hline $\begin{array}{l}\text { Caher, Republic } \\
\text { of Ireland }{ }^{g}\end{array}$ & $\mathrm{D}$ & 96 & $2.89(2.04)$ & $0.32(0.12)$ & $2.7 \times 10^{-2}$ & $7(0)$ & 14 & $11 *$ & $\begin{array}{l}\text { Bee Improvement } \\
\text { and Bee } \\
\text { Breeders' } \\
\text { Association, } \\
\text { Republic of } \\
\text { Ireland }\end{array}$ \\
\hline $\begin{array}{l}\text { Belfast, } \\
\text { Northern } \\
\text { Ireland }^{g}\end{array}$ & $\mathrm{D}$ & 96 & $7.54(3.87)$ & $0.64(0.12)$ & $1.0 \times 10^{-2}$ & $10(0)$ & 16 & $15 *$ & $\begin{array}{l}\text { Institute of } \\
\text { Northern } \\
\text { Ireland } \\
\text { Beekeepers, } \\
\text { U.K. }\end{array}$ \\
\hline $\begin{array}{l}\text { Gotland, } \\
\text { Sweden }^{g}\end{array}$ & $\mathrm{D}$ & 23 & $1.76(0.64)$ & $0.38(0.11)$ & $1.4 \times 10^{-2}$ & $2(0)$ & 3 & 9 & $\begin{array}{l}\text { Swedish } \\
\text { University of } \\
\text { Agricultural } \\
\text { Sciences, } \\
\text { Sweden }\end{array}$ \\
\hline
\end{tabular}

\footnotetext{
${ }^{a}$ Drone genotypes were obtained either directly, by genotyping drone samples collected at DCAs (D), or indirectly, by genotyping worker offspring of mated queens (W).

${ }^{b}$ Final sample sizes, given as the number of drone genotypes.

${ }^{c}$ Nondetection errors, calculated as in Boomsma and Ratnieks (1996).

${ }^{d}$ Number of colonies represented by at least a median number of drones, followed by the number of colonies remaining undetected because of an insufficient sample (in parentheses).

e Sample size corrected number of reconstructed drone-producing queens.

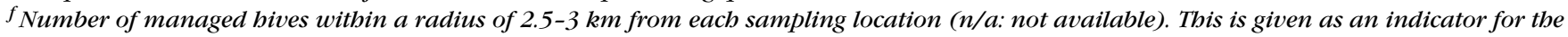
occurrence of putative wild colonies (cases where we estimated more colonies than the managed ones are indicated with and asterisk [*]). ${ }^{g}$ Samples genotyped using sets of five, five and four tightly linked microsatellite markers. These three linkage groups are located on different chromosomes: loci HB-16-01, ACOO6, HB-16-02, HB-16-03, HB-16-05 on chromosome 16; loci HB-THE-O1, HB-THE-02, HB-THE-03, HB-THE-O4, HB-THE-05 on chromosome 13; and loci HB-SEX-01, HB-SEX-02, HB-SEX-03, UN351 on chromosome 3 (Shaibi et al. 2008).

${ }^{b}$ Samples genotyped using one set of 12 linked microsatellites located on chromosome 16: loci HB-002, HB-005, HB-0O7, HB-008, HB-O1O, HB-012, HB-15, HB-016, HB-017, HB-018, HB-019, and SV-240. In the Tswalu sample, the individuals analyzed by Moritz et al. (2008) were pooled with additional drones that had been collected at this site at the same time.

${ }^{i}$ Beekeeping activity is absent in the area and thus the samples represent wild boneybee populations.

${ }^{j}$ Samples previously genotyped by Moritz et al. (2007) using 10 microsatellite markers. Their genotypic data were included in our study because a different approach was used here to estimate colony densities (see Methods).

${ }^{k}$ Samples genotyped using five unlinked microsatellite markers (A7, A24, A79, A107 and A113) in combination with the three sets of tightly linked microsatellite markers (Shaibi et al. 2008).

${ }^{l}$ Person or institution surveying the number of managed hives in the vicinity of our sampling locations.
}

The multilocus genotypes of the samples analyzed by Moritz et al. (2007) were directly introduced into COLONY to assign drones to colonies. In the samples analyzed with the linked markers, we first grouped all individuals sharing the same allelic combination at all loci within each linkage group. Individuals sharing a particular allelic combination were assigned to a single haplotype. Individuals that could not be assigned to a specific haplotype in at least one linkage group (because of low polymorphism or missamplifications at some loci) were excluded from all subsequent analyses. The haplotypes found in each linkage group were then used as individual alleles so that they could be introduced into COLONY. In the six samples in which only one set of linked markers was used for genotyping, we did not use COLONY because we did not have unlinked sets of markers. Instead, given that queens are diploid, we calculated a conservative estimate of the number of drone-producing queens by halving the sample-size-corrected number of haplotypes found in each population.

\section{Nondetection and Nonsampling Errors}

Two kinds of errors affected our estimated number of drone-producing queens. First, two identical genotypes could have been detected in two different individuals by chance (nondetection errors [NDEs]). The probability of this type of error is determined on the basis of the number of markers used and their level of polymorphism. We calculated this probability from the allele and haplotype frequencies in the samples analyzed with unlinked and linked markers, respectively, following Boomsma and Ratnieks (1996). Second, queens may have gone undetected because of an insufficient sample size (nonsampling errors). We assessed this type of error with a fitted Poisson distribution of the drones (obtained either 
directly or indirectly through worker offspring) among the assigned queens (Jaffé et al. 2009). The final samplesize-corrected number of queens (estimated number of colonies) was obtained by adding the undetected queens (those with an expected frequency of zero) to the detected ones at each location. In the six samples in which we used only one set of linked markers for genotyping, the sample-size-corrected number of haplotypes found in each population was obtained from the distribution of drones among the assigned haplotypes.

\section{Census of Managed Hives and Detection of Putative Wild Colonies}

The number of managed hives within a radius of 2.5-3 $\mathrm{km}$ from each sampling location were exhaustively surveyed by beekeepers or members of beekeeping organizations. We asked these people to conduct the surveys because of their knowledge of local beekeeping operations. Sites were mapped through the use of free geographic information system software available online (Google Maps). In contrast to official hive censuses, our surveys included "registered" hives, from professional beekeepers, and "unofficial" hives, belonging to unregistered amateurs. Censuses were taken during or shortly after each sampling event and therefore represent the local situation at the time the samples were collected. We subtracted the number of estimated colonies from the number of managed colonies surveyed at each location to infer the putative number of wild (i.e., unmanaged) honeybee colonies.

\section{Density Estimation}

Honeybee colonies are headed by a single queen (Seeley 1985), and therefore the number of queens detected at a given location provides an estimate of colony density. To calculate this density from the number of queens detected, it is necessary to know the distance over which drones and queens fly. Drones can only fly up to 7 $\mathrm{km}$ (Ruttner \& Ruttner 1972), and $15 \mathrm{~km}$ is the maximal mating distance (drone plus queen flight distance) ever recorded (Jensen et al. 2005). On average, however, drones fly between 600 and $1200 \mathrm{~m}$ (Taylor \& Rowell 1988). Taylor and Rowell (1988) and Koeniger et al. (2005) report the number of drones recaptured at different distances from source hives. On the basis of these distributions, we calculated an average drone flight distance of $900 \mathrm{~m}$. Therefore, in all subsequent density calculations, we used $900 \mathrm{~m}$ as the mean flight distance of drones and $2.5 \mathrm{~km}^{2}$ as the mean mating area of drones (assuming the area is circular). Comparing the two approaches for estimating colony number (genotyping drones vs. worker offspring), Moritz et al. (2008) found that the population size estimated with worker offspring is 1.8 times that obtained from a drone sample, presumably due to the greater flight range of queens plus drones. For this reason we considered the queen's mating area to be 1.8 times larger than that of drones $\left(4.5 \mathrm{~km}^{2}\right)$.

Using the total number of estimated colonies and the mean flight distance of drones to estimate the density of colonies, however, will inevitably overestimate colony density, given that distant colonies contributing drones to the DCA are considered within an average flight distance. Assuming a similar drone investment, distant colonies will contribute fewer drones than colonies located in the vicinity of a DCA, likely to be represented by many drones. For this reason we excluded those colonies represented by less than a median number of drones in all density calculations (the distribution of drones among colonies resembles a Poisson distribution; Baudry et al. 1998). For each location we therefore quantified the number of colonies represented by at least a median number of drones (Supporting Information). Dividing this number by the mean mating area of drones (for the drone samples) or queens (for the worker samples), we obtained an estimate of the local density of colonies at each sampling location.

\section{Statistical Analyses}

Except for gene diversity $\left(H_{e}\right)$ and NDEs, all variables (allelic richness, colony density, temperature, and rainfall) were normally distributed. The $H_{e}$ and NDE were therefore arcsine and $\log _{\mathrm{e}}$ transformed, respectively. Homoscedasticity was not violated in any case. Linear regressions were then performed to detect colinearity of variables. Because temperature was positively correlated with colony density and gene diversity, we performed analyses of covariance (ANCOVA) with colony density, gene diversity, and allelic richness as dependent variables, pattern of land use (agricultural land or nature reserve) as a categorical predictor, and temperature as a covariate. We repeated the ANCOVA considering only the 13 samples from European locations. Finally, we used a $t$ test to compare the mean density of honeybee colonies estimated in our 13 European locations with the mean density of managed hives of 33 European countries (calculated from Appendix I in De la Rúa et al. 2009).

\section{Results}

Genetic diversity measures were negatively correlated with NDE (AR-In NDE regression's beta $=-0.62$, $t_{23}=-3.81, p<0.001 ;$ arcsine $H_{e}$-ln NDE regression's beta $\left.=-0.50, t_{23}=-2.80, p=0.01\right)$. NDE, however, was not correlated with colony density (In NDE-density regression's $t_{23}=-1.62, p=0.12$ ). Genetic diversity was highest in South Africa and lowest in Northern Europe (Table 1). Likewise, the highest colony densities were found in South Africa 


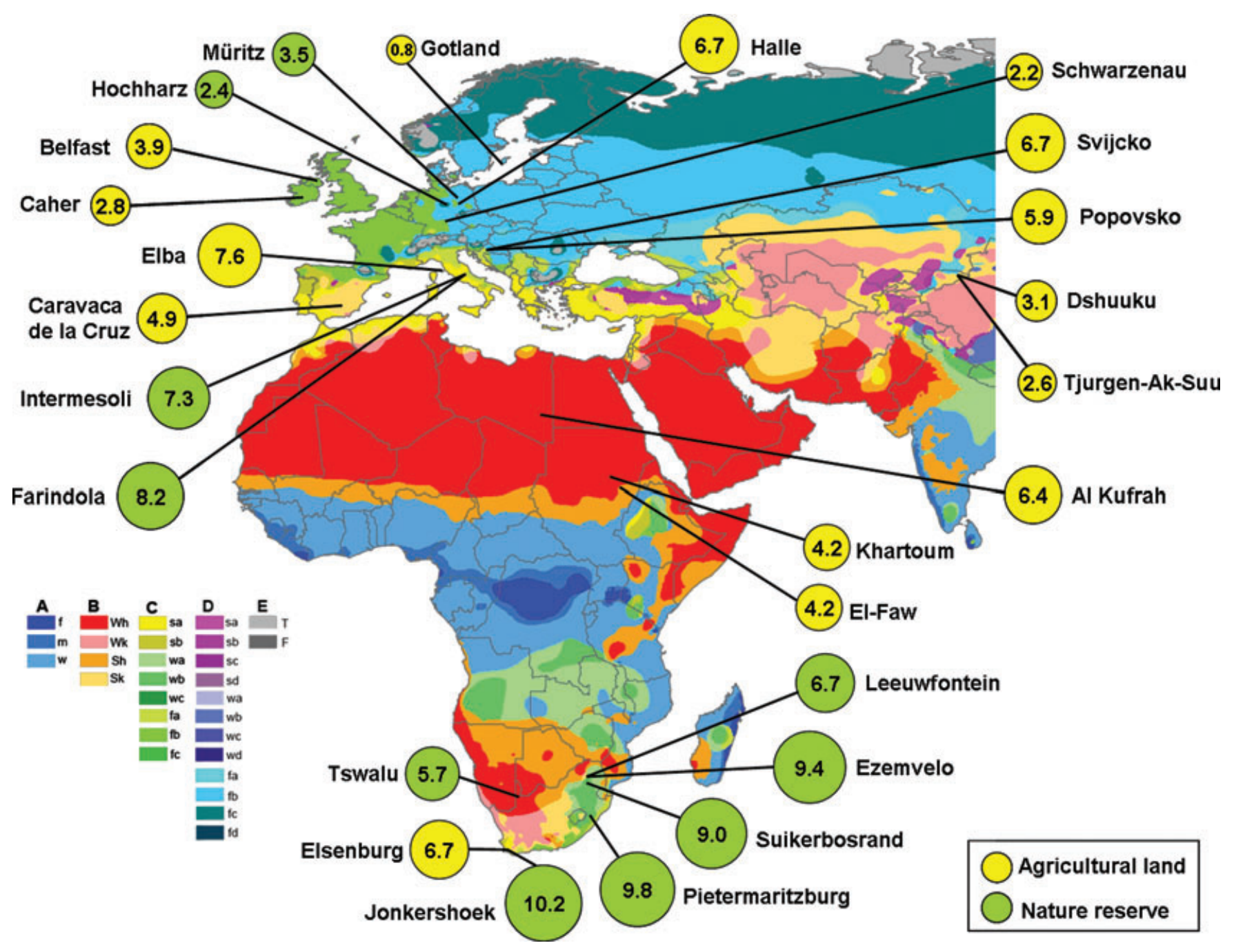

Figure 1. Apis mellifera colony densities at 10 locations in Africa, 2 locations in central Asia, and 13 locations in Europe. The diameter of the circles is proportional to the density at each location (given within the circle is the number of colonies per square kilometer), and color (yellow or green) indicates the pattern of land use (agricultural landscape or nature reserve respectively). The multicolor legend on the lower left relates to the Köppen climate classification map (adapted from Peel et al. [2007] and used bere under the Creative Commons Attribution, Noncommercial and ShareAlike License) (A, tropical/megathermal climates; B, dry [arid and semiarid] climates; $C$, temperate/mesothermal climates; $D$, continental/microthermal climates; $E$, polar climates [see Supporting Information for a detailed legend]).

( $>9$ colonies $/ \mathrm{km}^{2}$ ), whereas the lowest densities were found in northern Europe $\left(<3\right.$ colonies $/ \mathrm{km}^{2}$, Fig. 1). Genetic diversity measures correlated positively with colony density (AR-density regression's beta $=0.81$, $t_{23}=6.64, p<0.001 ;$ arcsine $H_{e}$-density regression's beta $\left.=0.70, t_{23}=4.68, p<0.001\right)$. Whereas average monthly rainfall was not correlated with any of our dependent variables (regression's $t_{23}<1, p>0.4$ in all cases), mean annual temperature was an important predictor of gene diversity (temperature-arcsine $H_{e}$ regression's beta $=0.54, t_{23}=3.04, p=0.006$ ) and of colony density (temperature-density regression's beta $=$ $0.41, t_{23}=2.18, p=0.04$; Fig. 2), but less so of allelic richness (temperature-AR regression's beta $=0.39, t_{23}=$ $2.04, p=0.05$ ). For this reason, we used temperature as a continuous predictor in the subsequent analyses of covariance.

Land use had a significant negative influence on genetic diversity measures and the density of honeybee colonies, even when accounting for temperature variation (AR: $F_{1,22}=10.60, p=0.004 ; H_{e}: F_{1,22}=12.99$, $p=0.002$; density: $F_{1,22}=8.36, p=0.008$ ). Overall, allelic richness, gene diversity, and colony density were higher in nature reserves (mean $[\mathrm{SD}]=11.88$ [4.30], 0.93 [0.12], and 7.23 [2.67], respectively) than in agricultural landscapes (mean [SD] $=7.46$ [2.67], 0.74 [0.17], 


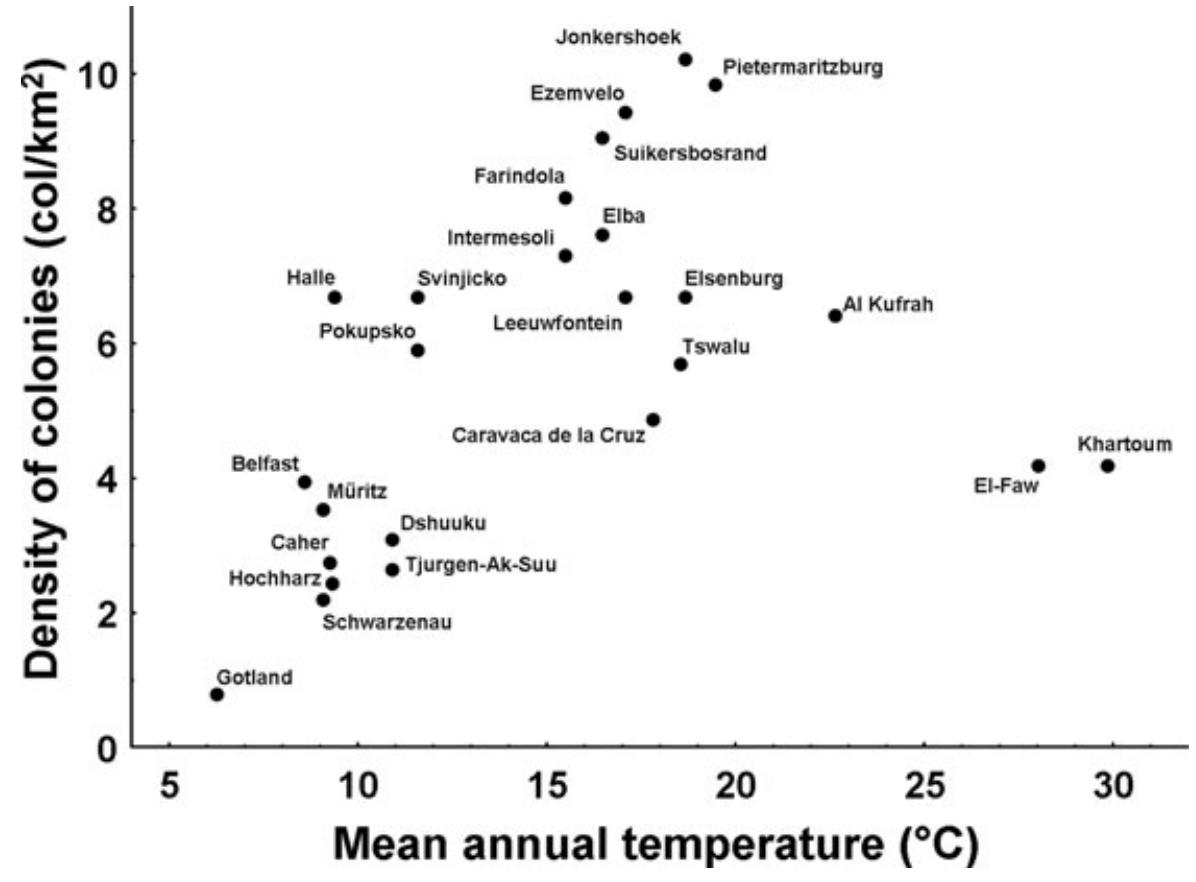

Figure 2. Variation in densities of honeybee colonies with mean annual temperature at 25 locations across Africa, Central Asia, and Europe. Temperature data were obtained from the World Meteorological Organization, the South African Weather Service, and the Meteorological and Hydrological service of Croatia (see Supporting Information). and 4.57 [2.03], respectively). Within Europe, however, nature reserves showed similar genetic diversity and colony densities as agricultural landscapes (AR: $F_{1,10}=$ $0.01 ; H_{e}: F_{1,10}=3.32$; density: $F_{1,10}=0.02 ; p \geq 0.1$ in all cases). Putative wild (unmanaged) honeybees in Europe were only identified in Ireland and Italy, where we detected more colonies among genotypic samples than those kept by local beekeepers (Table 1). Finally, the mean density of honeybee colonies estimated across the 13 European sampling locations (Table 1) did not differ from the average density of managed hives reported in a recent survey (De la Rúa et al. 2009) of 33 European countries (estimated mean density $[\mathrm{SD}]=4.83$ [2.39], mean density of managed hives $[\mathrm{SD}]=4.04$ [2.82], $t_{44}=$ $0.89, p=0.4)$.

\section{Discussion}

Our estimates of the density of honeybee colonies were directly dependent on the number of genetic markers used and their level of polymorphism. Although our detection power was affected by the level of genetic diversity at each location, NDEs and colony densities were not correlated, which shows that NDEs had little impact on our estimates. Sampling biases caused by seasonality, on the other hand, represented a more important source of inaccuracy in our estimation of colony numbers (Hepburn \& Radloff 1998; Jaffé et al. 2009). The samples from Europe and central Asia were collected in late spring through summer, near the drone production peak; and hence, we expect to have detected most of the reproductively active colonies at each sampling location.
In our selected African locations, where seasonality is not as clear-cut and pronounced as in temperate regions, avoiding the effects of seasonality was more difficult. Nevertheless, sampling was performed during summer and rainy months, when enough floral resources were available to colonies for growth and reproduction, which minimized the occurrence of colonies not investing in drone production. An additional source of potential bias in our density estimates is that queen and drone flight distances may differ among honeybee subspecies or sampling locations. Unfortunately, data are not available on the impact of environmental or genetic factors on the flight distance of drones or queens. Despite these limitations, the estimated number of colonies remaining undetected because of an insufficient sample was usually low (Table 1). Moreover, our local density estimates matched previously reported values (Otis 1991; Ratnieks et al. 1991; McNally \& Schneider 1996; Baum et al. 2008; but see Oldroyd et al. 1997); and hence, we are confident they provide an informative picture of the reproductively active colonies found at our different sampling locations.

In our study genetic diversity and the density of honeybee populations were strongly influenced by the mean annual temperature. Brood production and reproductive swarming are determined by the availability of forage and the ability of bees to gather nectar and pollen (Hepburn \& Radloff 1998). Rainfall is an important predictor of forage availability in dry, seasonal ecosystems, such as those of our African locations. In our global analysis, however, rainfall was not correlated either with genetic diversity or colony density. A possible explanation of this finding is that temperature is likely to be a more important predictor of colony densities in temperate climates, where 
honeybees must stay inside their colonies and cease foraging activities in winter. The relationship between temperature and the density of honeybee colonies, however, seemed to be linear only with annual temperatures below $25^{\circ} \mathrm{C}$ (Fig. 2). Above this threshold value, extreme temperatures are likely to constrain the foraging ability of bees and reduce colony densities (Afik \& Shafir 2007).

Nonclimatic factors are also likely to influence genetic diversity and colony densities in honeybee populations. African and European honeybees, for instance, differ in many life-history traits. African subspecies disperse via long-distance migratory swarms, leave the nest in response to disturbance or disease (absconding) more readily, and have a faster generation time and smaller colonies than European honeybees (reviewed by Schneider et al. 2004). These traits promote population gene flow and high genetic diversity, boosting effective population sizes in Africa (Estoup et al. 1995; Jaffé et al. 2009). The impact of such subspecific differences on colony density estimates, however, is not clear. Whereas the density of wild honeybee colonies in Botswana is $<5$ colonies $/ \mathrm{km}^{2}$ (McNally \& Schneider 1996; see also Hepburn \& Radloff 1998 and references therein), estimates for feral Africanized colonies in the Neotropics span 6-20 colonies/ $\mathrm{km}^{2}$ (Otis 1991; Ratnieks et al. 1991). These figures overlap with the densities of European colonies we found $(<1$ to $>8$ colonies $/ \mathrm{km}^{2}$; Fig. 1). Moreover, even though honeybees of African origin replaced European honeybees in the American tropics, an 11-year study in a Texan nature reserve shows that both can establish similar colony densities in temperate regions (Pinto et al. 2004).

Beekeeping practices can also have a profound influence over wild and feral honeybee populations (De la Rúa et al. 2009). Coexistence with managed bees exposes feral and wild populations to bee pathogens and to introgressive hybridization. Apiculture typically involves the concentration of colonies in apiaries, which facilitates the horizontal transfer of pathogens and parasites from colony to colony (Fries \& Camazine 2001). This can have catastrophic consequences, as demonstrated by the drastic decline of feral U.S. bee populations after the introduction of parasitic Varroa mites in the 1980s (Kraus \& Page 1995; Needham et al. 1988). Indeed, honeybee colonies in northern latitudes do not usually survive infestation by Varroa mites without treatment (Fries et al. 2006). Given the extent of the beekeeping industry in Europe, human-mediated disease dissemination is expected to cause important declines in European honeybee populations (De la Rúa et al. 2009).

In addition to hosting an extensive beekeeping industry, most European countries have intensive land use. The human-mediated destruction of natural habitats has led to a progressive reduction of suitable habitats for honeybees, with a negative impact on feral and wild populations (Biesmeijer et al. 2006; Fitzpatrick et al. 2007). Agricultural intensification and forestry reduce the diver- sity and abundance of native bees in the United States, which diminishes their pollination services by 3- to 6fold (Kremen et al. 2002). In support of these findings, we found lower genetic diversity and colony densities in agricultural landscapes than in nature reserves. Restricting the analysis to Europe, however, erased the significant effect of land use, making agricultural landscapes and nature reserves indistinguishable in terms of genetic diversity or colony density. This may partially be due to the fact that variation in land-use patterns is much larger between than within continents. We nevertheless caution that other factors that we did not consider are also likely to affect the relationship between land use and the density of honeybee colonies (e.g., Winfree et al. 2007). More thorough comparisons, with larger sample sizes and that control for multiple factors, are needed to assess the extent to which land use is detrimental to honeybee populations. Only two of our sampling locations provided a test case to address the effect of land use on honeybee colony densities: the deforested farmland of Elsenburg and the neighboring nature reserve of Jonkershoek, $20 \mathrm{~km}$ apart, where no beekeeping takes place. Both share similar climatic conditions and a honeybee subspecies (A.m. capensis) that is tolerant to Varroa mites (Allsopp 2006). Habitat destruction thus seems to be the main factor responsible for the lower colony density observed in Elsenburg.

Another explanation for the lack of a difference in genetic diversity and colony densities between agricultural landscapes and nature reserves in Europe is that wild honeybee populations may be absent from nature reserves. For instance, we did not detect a higher number of colonies in most European sampling locations compared with those kept by local beekeepers. Only in the Italian nature reserve surrounding Farindola, did we detect a large excess of colonies compared with the number kept by local beekeepers (Table 1). Hence, we were more confident about the presence of wild bees in this location. At the European scale, our mean estimated density of honeybee colonies closely resembled the average density of managed hives reported by De la Rúa et al. (2009), which suggests that the European honeybee populations we studied here were mainly composed of managed bees.

As disease dissemination and land use continue to threaten European honeybees (Brown \& Paxton 2009), only populations managed by beekeepers are likely to survive. Although we cannot discount apiculture itself as involved in the decline of wild European honeybees, our data suggest that without beekeeping, honeybees in Europe would be close to extinction. Our estimates of honeybee population density across Europe were in the same range as those found in the adverse climatic conditions of the Kalahari and Saharan deserts (Fig. 1), which suggests that beekeeping activities do not compensate for the loss of wild honeybee colonies. Moreover, the current pollination services provided by honeybees might 
not fulfill agricultural demand (Aizen \& Harder 2009). Added to the parallel decline of other pollinators, honeybee losses could therefore seriously threaten pollination services and ecosystem functioning in Europe. Because honeybees are "rescue pollinators" and thus able to compensate for the decline of native pollinators in degraded habitats (Aizen \& Feinsinger 1994; Dick 2001), we suggest that promoting beekeeping activities could compensate for habitat loss and ensure adequate pollination of wild plants and crops. In the light of severe declines in beekeeping activities in various European countries (COLOSS 2009), we recommend that beekeeping with local subspecies should be encouraged to preserve native genetic diversity and to reduce the transmission of pathogens throughout the continent (De la Rúa et al. 2009). A first step toward this could be to reconsider the conservation status of honeybees in Europe and to regard beekeeping not only as a profitable business for producing honey, but also as an essential component of biodiversity conservation.

\section{Acknowledgments}

We are grateful to P. Leibe, D. Kleber, A. G. Sabatini, M. Mac Giolla Coda, and H. H. Kaatz for providing valuable support and to E. O. Oppenheimer \& Sons and Cape Nature for allowing us access to the Tswalu and Jonkershoek reserves, respectively. We thank the entire BEESHOP team for stimulating and fruitful discussions during our meetings and R. Hepburn and three anonymous referees for their helpful suggestions on the manuscript. This project was funded by the BEESHOP European network (FOOD-CT-2006-022568) and the National Research Foundation of South Africa.

\section{Supporting Information}

The coordinates and climatic data for all sampling locations (Appendix S1), a schematic representation of our approach to estimate honeybee colony densities (Appendix S2), and the Köppen climate classification detailed legend (Appendix S3) are available as part of the on-line article. The author is responsible for the content and functionality of these materials. Queries (other than absence of the material) should be directed to the corresponding author.

\section{Literature Cited}

Afik, O., and S. Shafir. 2007. Effect of ambient temperature on crop loading in the honey bee, Apis mellifera (Hymenoptera: Apidae). Entomoligia Generalis 29:135-148.

Aizen, M. A., and L. D. Harder. 2009. The global stock of domesticated honey bees is growing slower than agricultural demand for pollination. Current Biology 19:1-4.
Aizen, M. A., and P. Feinsinger. 1994. Forest fragmentation, pollination, and plant reproduction in a Chaco dry forest, Argentina. Ecology 75:330-351.

Allen-Wardell, G., et al. 1998. The potential consequences of pollinator declines on the conservation of biodiversity and stability of food crop yields. Conservation Biology 12:8-17.

Allsopp, M. H. 2006. Analysis of Varroa destructor infestation of southern African honeybee populations. MS thesis. Faculty of Natural \& Agricultural Science, University of Pretoria, Pretoria.

Allsopp, M. H., W. J. De Lange, and R. Veldtman. 2008. Valuing insect pollination services with cost of replacement. Public Library of Science ONE e3128: 1-8. DOI:10.1371/journal.pone.0003128.

Baum, K. A., M. D. Tchakerian, S. C. Thoenes, and R. N. Coulson. 2008. Africanized honey bees in urban environments: a spatio-temporal analysis. Landscape and Urban Planning 85:123-132.

Baudry, E., M. Solignac, L. Garnery, M. Gries, J. M. Cornuet, and N. Koeniger. 1998. Relatedness among honeybees (Apis mellifera) of a drone congregation. Proceedings of the Royal Society of London B Biological Sciences 26:2009-2014.

Biesmeijer, J. C., et al. 2006. Parallel declines in pollinators and insectpollinated plants in Britain and the Netherlands. Science 313:351354.

Boomsma, J. J., and F. L. W. Ratnieks. 1996. Paternity in eusocial Hymenoptera. Philosophical Transactions of the Royal Society B Biological Sciences 351:947-975.

Brown, M. J. F., and R. J. Paxton. 2009. The conservation of bees: a global perspective. Apidologie (special issue) 40:410-416.

Buchmann, S., and G. Nabhan. 1996. The forgotten pollinators. Island Press, Washington, D.C.

COLOSS (International Network for the Prevention of Honeybee Colony Losses). 2009. Proceedings of the 4th COLOSS conference: prevention of honeybee colony losses. Available from http://www.coloss.org/publications/Zagreb\%20Proceedings (accessed June 2009).

Costanza, R., et al. 1997. The value of the world's ecosystem services and natural capital. Nature 387:253-260.

De la Rúa, P., R. Jaffé, R. Dall 'Olio, I. Muñoz, and J. Serrano. 2009. Biodiversity, conservation and current threats to European honeybees. Apidologie (special issue) 40:263-284.

Dick, C. W. 2001. Genetic rescue of remnant tropical trees by an alien pollinator. Proceedings of the Royal Society of London B Biological Sciences 268:2391-2396.

Estoup, A., M. Solignac, and J. M. Cornuet. 1994. Precise assessment of the number of patrilines and of genetic relatedness in honeybee colonies. Proceedings of the Royal Society of London B Biological Sciences 258:1-7.

Estoup, A., L. Garnery, M. Solignac, and J. M. Cornuet. 1995. Microsatellite variation in honey bee (Apis mellifera L.) populations: hierarchical genetic structure and test of the Infinite Allele and Stepwise Mutation Models. Genetics 140:679-695.

Fitzpatrick, Ú., T. E. Murray, R. J. Paxton, J. Breen, D. Cotton, V. Santorun, and M. J. F. Brown. 2007. Rarity and decline in bumblebees - a test of causes and correlates in the Irish fauna. Biological Conservation 136:185-194.

Free, J. B. 1993. Insect pollination of crops. Academic Press, London.

Fries, I., A. Imdorf, and P. Rosenkranz. 2006. Survival of mite infested (Varroa destructor) honey bee (Apis mellifera) colonies in a Nordic climate. Apidologie 37:564-570.

Fries, I., and S. Camazine. 2001. Implications of horizontal and vertical pathogen transmission for honey bee epidemiology. Apidologie 32:199-214.

Gallai, N., J M. Salles, J. Settele, and B. E. Vaissière. 2009. Economic valuation of the vulnerability of world agriculture confronted with pollinator decline. Ecological Economics 68:810821.

Ghazoul, J. 2005. Buzziness as usual? Questioning the global pollination crisis. Trends in Ecology \& Evolution 20:367-373. 
Goudet, J. 2002. FSTAT. Version 2.9.3.2. Department of Ecology \& Evolution, Lausanne, Switzerland. Available from http:// www2.unil.ch/popgen/softwares/fstat.htm (accessed May 2008).

Hepburn, H. R., and S. E. Radloff. 1998. Honeybees of Africa. SpringerVerlag, Berlin.

Huryn, V. M. B. 1997. Ecological impacts of introduced honey bees. Quarterly Review of Biology 72:275-297.

Jaffé R., V. Dietemann, R. M Crewe, and R. F. A. Moritz. 2009. Temporal variation in the genetic structure of a drone congregation area: an insight into the population dynamics of wild African honeybees (Apis mellifera scutellata). Molecular Ecology 18:1511-1522.

Jensen, A. B., K. A. Palmer, N. Chaline, N. E. Raine, A. Tofilski, S. J. Martin, B. V. Pedersen, J. J. Boomsma, and F. L. W. Ratnieks. 2005. Quantifying honey bee mating range and isolation in semi-isolated valleys by DNA microsatellite paternity analysis. Conservation Genetics 6:527-537.

Kearns, C. A., D. W. Inouye, and N. M. Waser. 1998. Endangered mutualisms: the conservation of plant-pollinator interactions. Annual Review of Ecology and Systematics 29:83-112.

Klein, A. M., B. E. Vaissiére, J. H. Cane, I. Steffan-Dewenter, S. A. Cunningham, C. Kremen, and T. Tscharntke. 2007. Importance of pollinators in changing landscapes for world crops. Proceedings of the Royal Society of London B Biological Sciences 274:303313.

Koeniger N., G. Koeniger, and H. Pechhacker 2005. The nearer the better? Drones (Apis mellifera) prefer nearer drone congregation areas. Insectes Sociaux 52:31-35.

Kraus, B., and R. E. Page Jr. 1995. Effect of Varroa jacobsoni (Mesostigmata Varroidae) on feral Apis mellifera (Hymenoptera: Apidae) in California. Environmental Entomology 24:1473-1480.

Kremen, C., N. M. Williams, and R. W. Thorp. 2002. Crop pollination from native bees at risk from agricultural intensification. Proceedings of the National Academy of Sciences of the United States of America 99:16812-16816.

Matheson, A., S. L. Buchmann, C. O'Toole, P. Westrich, and I. H. Williams. 1996. The conservation of bees. Academic Press, London.

McNally, L. C., and S. S. Schneider. 1996. Spatial distribution and nesting biology of colonies of the African honey bee Apis mellifera scutellata (Hymenoptera: Apidae) in Botswana, Africa. Environmental Entomology 25:643-652.

Moritz R. F. A., and E. E. Southwick. 1995. Bees as superoragnisms: an evolutionary reality. Springer-Verlag, Berlin.

Moritz, R. F. A., S. Härtel, and P. Neumann. 2005. Global invasions of the western honey bee (Apis mellifera) and the consequences for biodiversity. Ecoscience 12:289-301.

Moritz, R. F. A., F. B. Kraus, P. Kryger, and R. M. Crewe. 2007. The size of wild honeybee populations (Apis mellifera) and its implications for the conservation of honeybees. Journal of Insect Conservation 11:391-397.

Moritz, R. F. A., V. Dietemann, and R. M. Crewe. 2008. Determining colony densities in wild honeybee populations (Apis mellifera) with linked microsatellite DNA markers. Journal of Insect Conservation 12:455-459.

Morse, R. A., and N. W. Calderone. 2000. The value of honey bees as pollinators of US crops in 2000. Bee Culture 128:1-15.

Needham, G. R., R. E. Page Jr., M. Delfinado-Baker, and C. E. Bowman, editors. 1988. Africanized bees and bee mites. Ellis Horwood, Chichester, United Kingdom.

Otis, G. W. 1991. Population biology of the Africanized honey bee. Pages 213-234 in M. Spivak, D. J. C. Fletcher, and M. D. Breed, editors. The "African" honey bee. Westview Press, Boulder, Colorado.

Oldroyd, B. P., E. G. Thexton, S. H. Lawler, and R. H. Crozier. 1997. Population demography of Australian feral bees (Apis mellifera). Oecologia 111:381-387.
Paini, D. R. 2004. Impact of the introduced honey bee (Apis mellifera) (Hymenoptera: Apidae) on native bees: a review. Austral Ecology 29:399-407.

Peel, M. C., B. L. Finlayson, and T. A. McMahon. 2007. Updated world map of the Köppen-Geiger climate classification. Hydrology and Earth System Sciences 11:1633-1644.

Pinto, M. A., W. L. Rubink, R. N. Coulson, J. C. Patton, and J. S. Johnston. 2004. Temporal pattern of Africanization in a feral honeybee population from Texas inferred from mitochondrial DNA. Evolution 58:1047-1055.

Ratnieks, F. L. W., M. A. Piery, and I. Cuadriello. 1991. The natural nest and nest density of the Africanized honey-bee (Hymenoptera, Apidae) near Tapachula, Chiapas, Mexico. Canadian Entomologist 123:353-359.

Roubik, D. W. 1989. Ecology and natural history of tropical bees. Cambridge University Press, Cambridge, United Kingdom.

Roubik, D. W., and H. Wolda. 2001. Do competing honey bees matter? Dynamics and abundance of native bees before and after honey bee invasion. Population Ecology 43:53-62.

Ruttner, H., and F. Ruttner. 1972. Untersuchungen über die Flugaktivität und das Paarungsverhalten der Drohnen. V. Drohnensammelplätze und Paarungsdistanz. Apidologie 3:203-232.

Ruttner, F. 1988. Biogeography and taxonomy of honeybees. Springer Verlag, Berlin.

Schneider, S. S., G. DeGrandi-Hoffman, and D. R. Smith. 2004. The African honey bee: factors contributing to a successful biological invasion. Annual Review of Entomology 49:351-376.

Seeley, T. D. 1985. Honeybee ecology. Princeton University Press, Princeton, New Jersey.

Shaibi, T., H. M. G. Lattorff, and R. F. A. Moritz. 2008. A microsatellite DNA toolkit for studying population structure in Apis mellifera. Molecular Ecology Resources 8:1034-1036.

Southwick, E. E., and L. Southwick. 1992. Estimating the economic value of honey bees (Hymenoptera: Apidae) as agricultural pollinators in the United States. Journal of Economic Entomology 85:621633.

Taylor, O. R., and G. A. Rowell. 1988. Drone abundance, queen flight distance, and the neutral mating model for the honeybee, Apis mellifera. Pages 173-183 in G. R. Needham, R. E. Page Jr., M. DelfinadoBaker, and C. E. Bowman, editors. Africanized bees and bee mites. Ellis Horwood, Chichester, United Kingdom.

Van Engelsdorp, D., J. Hayes Jr., R. M. Underwood, and J. Pettis. 2008. A survey of honey bee colony losses in the U.S., Fall 2007 to Spring 2008. Public Library of Science ONE e4071: 1-6. DOI:10.1371/journal.pone.0004071.

Walsh, P. S., D. A. Metzger, and R. Higuchi. 1991. Chelex $100^{\mathrm{TM}}$ as a medium for simple extraction of DNA for PCRbased typing from forensic material. Biotechniques 10:506513.

Wang, J. 2004. Sibship reconstruction from genetic data with typing errors. Genetics 166:1963-1979.

Whitfield, C. W., S. K. Behura, S. H. Berlocher, A. G. Clark, J. S. Johnston, W. S. Sheppard, D. R. Smith, A. V. Suarez, D. Weaver, and N. D. Tsutsui. 2007. Thrice out of Africa: ancient and recent expansions of the honey bee, Apis mellifera. Science 314:642645.

Wildlife and Countryside Act 1981. Available from http://www. jncc.gov.uk/page-3614 (accessed March 2009).

Williams, J. L. 1987. Wind-directed pheromone trap for drone honey bees (Hymenoptera: Apidae). Journal of Economic Entomology 80:532-536.

Winfree, R., T. Griswold, and C. Kremen. 2007. Effect of human disturbance on bee communities in a forested ecosystem. Conservation Biology 21:213-223. 